spirit in which it was offered. It is a happy memory that we were able to send him two essays on a subject of which he himself was a master.

G. G.

\title{
SAMUEL DUMAS
}

ON 24 September 1938 quite unexpectedly there died in his 57 th year Professor Dr S. Dumas, the universally known and highly respected Chief of the Swiss Federal Assurance Bureau and a Corresponding Member of the Institute of Actuaries.

Born in a minister's family he was a native of the district at the foot of the Jura and passed through the literary side of the Gymnasium at Lausanne in order to devote himself later to the study of mathematics and physics at the Federal Technical High School and at Zurich University. At the High School he gained the 'Teachers' Diploma for mathematics and at the University the degree of Doctor of Philosophy for his dissertation on The Development of Elliptic Functions as Continued Fractions.

In $19{ }^{\circ} 5$ he was appointed Actuary to the Federal Statistical Office. At that time he was attending the lectures of Professor Moser at the University, Bern, on Insurance Mathematics, and his acquaintance with insurance science thus obtained was of great importance in the further development of the young actuary. In the following year he entered the Federal Assurance Bureau where for more than seven years he held first the position of technical assistant and afterwards that of actuary, thereby having the opportunity to make himself familiar with all the questions of insurance technique and State supervision. Amongst the many publications from his pen on assurance questions at this time his study of the question of war risk in life assurance is specially worthy of note.

In I91 $_{3}$ his cantonal government appointed him Professor for Financial Mathematics and Insurance Technique in the University of Lausanne, and he became also consulting actuary to the Life Assurance Company "La Suisse". The Swiss Government also enlisted his help in the difficult negotiations arising out of the necessities of German Life Assurance Companies. When, therefore, in the year 1924 the position of Director of the Federal Assurance Bureau became vacant he was appointed by the Federal Government to this responsible post. 'This restricted his activities as a teacher at the University in Lausanne but he did not have to give it up entirely, and the combination of theory and practice proved a great help in his management of the Bureau.

The last I3 years have been perhaps the most important and most difficult since the introduction of Swiss State supervision. Under the care of Professor Dumas the liquidation of the German life assurance contracts was completed. The preliminary work, which had commenced 
before his time, for a federal law to render secure the claims arising from the policies of native life assurance companies was brought to an end, the law itself was passed and in the year $193 x$ the regulations for bringing it into force were framed by the Federal Bureau and passed by the Government. Simultaneously the difficult questions of Group Assurance and other assurance schemes of a similar character required suitable regulation. On the investment side the introduction of the new Bond Law required that the fixing of reserves and the valuation of securities should be examined anew as did also the prescriptions of foreign states as to the movement of capital, a matter of great importance in the international conduct of assurance business. All these tasks were successfully carried out, thanks to the outstanding ability of the man at the head of affairs. Completely master of his work, he understood well how to obtain the co-operation of his officials in whom he created both good will and confidence.

In the domain of pure science the valuation of probabilities particularly interested him as a philosopher. A whole series of works from his pen concerns these problems and their solution, for instance, the fundamental work Sur la définition de la probabilité in Volume IV of the Commentarii Mathematici Helvetici, Les probabilités inverses et la construction des tables de mortalité in the edition prepared in honour of Moser, and his contribution at the Stockholm International Congress, The Problem of Risk.

Excellent of its kind and typical in its mathematical presentation is his work on Mortality tables giving the same policy values, a translation of which appeared in F.I.A. Vol. LxIr. Together with Schaertlin and Moser, Dumas has with his work done most to enhance the reputation of Swiss Insurance Science in international circles. For many years he was President, and for some time since Honorary Member, of the Association of Swiss Actuaries whom he represented in the Council of the Permanent Committee for International Congresses, of which he was a VicePresident. Of his reputation abroad his appointments as Corresponding Member of the French, English, Belgian and Italian leading Actuarial Associations is sufficient evidence.

In addition to his official duties he was regarded by the Government as a trusted adviser in important money matters.

In the untimely death of this great man the profession has suffered a great loss. Like many such he was extraordinarily modest and truly noble minded. He was a great lover of nature and of his beautiful Fatherland, which he knew as only those can who spend their holidays in walking.

G. G. 